\title{
Benign Orbit Neoplasm
}

National Cancer Institute

\section{Source}

National Cancer Institute. Benign Orbit Neoplasm. NCI Thesaurus. Code C3620.

A non-metastasizing neoplasm that arises from the orbit. 